\title{
Impact of Human and Innovative Potential on the Region's Economic Growth
}

\author{
Anastasia Glotova \\ Department of Applied Economics and Economic Security \\ Belgorod State National Research University \\ Belgorod, Russia \\ glotova@bsu.edu.ru \\ Tatiana Dobrodomova \\ Department of Applied Economics and Economic Security \\ Belgorod State National Research University \\ Belgorod, Russia \\ dobrodomova_t@bsu.edu.ru
}

\author{
Irina Titova \\ Department of Management and Marketing \\ Belgorod State National Research University \\ Belgorod, Russia \\ titova@bsu.edu.ru
}

\begin{abstract}
The purpose of this study is to quantify the impact of human and innovation potential on the level of GRP per capita. For this purpose, the regions of the Central Federal district were grouped based on data for 2018. In defining economic development suggested indicators: public expenditure on education, share of employed population with higher education, per capita income, expenditure on technological innovations, the proportion of the number of researchers in the total population, innovative activity of the organizations. Using the method of statistical grouping and analysis of variance, we established a close relationship between the level of human and innovation potential and the level of economic development, and also determined the share of variation in GRP, which is explained by each of the factors. Based on the findings, the article suggests regional policy directions for accumulating human potential and increasing innovation activity in the region to increase the level of GRP per capita.
\end{abstract}

Keywords - human potential, innovation potential, economic growth, gross regional product, regions of the Central Federal district, variance analysis, grouping, median value Introduction.

\section{INTRODUCTION}

Currently, the main strategic goal for the development of regions, individual countries, and the world as a whole is the transition to an innovative economy. The social and economic potential of the territory makes it possible to develop an innovative economy. And of course, national wealth, as a source of competitive advantages of individual regions and countries, occupies a large share in the social and economic potential of the territory. What does national wealth consist of? According to research by world Bank experts, in the structure of national wealth of the world's countries, sixteen percent is physical capital, twenty percent is natural capital, but the share of human capital is about sixty-four percent. But this situation is not observed in all countries, for example, in countries such as Germany, Japan and Sweden, human capital occupies about eighty percent, but in Russia, in the structure of national wealth, human capital is only about fifty percent.

This situation dates back to the 90 - ies of the last century, when there was a depopulation of the population in both qualitative and quantitative terms, which led to a threat to the national security of the country.

At the same time, a new direction of development appeared in the theory of economic growth, which became known as the "new theory of growth". As a result of this new direction of development, scientific and technological progress has become considered as an endogenous factor, that is, a factor of economic growth that occurs under the influence of internal causes.

The new growth theory was developed by Paul Romer, a Professor of Economics at the New York University school of business. In their research, American economists P. Romer and R. Lucas developed formalized economic and mathematical models in which they hypothesized the endogenous nature of the most important industrial and technical innovations based on investments in technological progress and human capital $[11,15]$.

The peculiarity of endogenous economic growth theories is that they reject the neoclassical premise of diminishing marginal productivity of capital, but at the same time allow for the possibility of economies of scale within the entire economy. At the same time, theories of endogenous economic growth often focus on the impact of external effects on the return on investment. In addition to features, the theory of endogenous economic growth has its own differences and the main one is that this theory advocates active state intervention in the development process. 
The existence of different theories of endogenous growth allowed us to make a formal connection between the mechanisms of economic growth and the processes of obtaining and accumulating new knowledge, which can then be implemented in technological transformations. These theories allow us to analyze the economic growth rates of individual countries and the reasons for their differences, assess the effectiveness of state scientific, technical and industrial policies, and the impact of international integration and trade processes on economic growth. It should also be emphasized that the theory of endogenous economic growth, in its essence, is the scientific basis of the doctrine of human development, since the basis of the theory of endogenous growth is precisely that the person is the driving force of economic growth and a tool for achieving material wellbeing. In this regard, we can generalize and Express new theories of endogenous growth as follows: the best strategy that contributes to the increase of national income, and the accumulation of human capital, not physical, i.e. human development.

However, as practice shows, very often human capital is used unproductively, there is employment of the population not on the basis of qualifications, jobs do not meet the requirements, and many other cases. Accordingly, there is a need for the formation and implementation of human capital in favorable conditions, and this in turn will have a positive impact on the innovative development of regions and the country as a whole. This creates the inevitability of research and promotion of the mechanism of human capital management. This management mechanism will take into account the structure of human capital, the interdependence of the processes of formation and use, which will increase innovation activity in the regions and the country as a whole.

Human capital is presented as a key development factor in all the strategic documents of the Russian Federation's constituent entities, the concept of long-term socio-economic development of the Russian Federation for the period up to 2025 , and should have a high quality for the development of the innovative economy of the territories, which will significantly increase the growth rate of the main socioeconomic indicators of development of both regions and the country as a whole.

To date, a lot of research is devoted to the preparation of theoretical and methodological materials for assessing the impact of human capital on the socio-economic processes of territorial development, and interest in this is constantly growing. However, this did not solve the problems and controversial issues that arise when defining the concept of "human capital", its structural components, as well as when quantifying the nature of the impact of human capital on the results of economic activity and on the innovative development of territories. But despite all this, this problem remains relevant and requires additional research in the field of human capital and its impact on the innovative development of territories [3].

The variety of theories of endogenous economic growth can be divided into groups. Thus, the first group includes the theories of P. Romer (1986) and R. Lucas (1988), in which human capital is the most important element of economic growth. In their theory, they demonstrate the possibility of sustainable growth with a constant growth rate based on technological progress, which is a consequence of training employees in the process of activity. The result of this process is assigned by firms as an external effect. The constant growth rate depends on behavioral parameters (rates of intertemporal consumer preferences, state policy) $[11,15]$.

In the second group, the most popular are the works of Grosman and Helpman, R., R. Barro and K. Sala-I-Martin, who in their research tried to link endogenous technological changes and international trade, openness [5,14,18].

Separately, there are models linking growth with uneven distribution of wealth, these are the models of Alesina and Rodrik [1].

The study of the concept of "human capital" is devoted to the works of Dobrynin A. I., Dyatlov S. A., Kapelyushnikov R. I., Lukyanova A. L., which study approaches to the definition of human capital, as well as structural components and their impact on the results of economic activity $[6,7,8$,$] .$ Dobrokhleb V. G., Bochkareva V. K., Migranov L. A., Molchanova E. V., Toksanbayeva M. S., Rimashevskaya N. M. evaluated the quality of human potential in the conditions of innovative economy in their works $[13,14]$. They pay special attention to the study of human capital, taking into account the influence of education on the quality of labor potential on its formation and ways to improve it. But such scientists as V. A. Ilyin and A. A. Shabunova study the theoretical and methodological foundations in the field of sociological measurements of the quality of the working-age population [10]

Both foreign and domestic researchers influence the development of the methodology of human capital research, taking into account innovative transformations of the territory. But the main theoretical aspects of human capital management as a determining factor of economic development can be seen in the works of Bychenko Yu. G. and Pikhtelev a.m.,., cretsky M. M., Skoblyakova I. V. $[3,9,17]$.

In Russian economic science, namely, in the works of $\mathrm{O}$. G. Golichenko, the problems of formation of educational services markets in the conditions of transition to an innovative economy are considered, while certain parameters of knowledge production and mechanisms of technology transfer are studied. All this research is related to the study of problems in the innovation sphere, namely, the study of the performance of researchers [4].

As for research on the impact of the educational and professional level of the population on the amount of their income, this can be found in the works of G. Becker and J. Minzer [2, 12]. Issues related to the formation and development of innovative skills, including through.

\section{METHODS}

The algorithm for assessing the impact of the level of human capital and innovative development of the region on economic growth involves solving the following tasks:

1.Collection of primary data and calculation of indicators required for this study.

The information base of the study was Rosstat data for 2018 for the Central Federal district regions. The definition and justification of the variables required for the study is presented in table 1 . 


\section{Normalization of indicators}

When checking the symmetry of the distribution data for each indicator, it was found that the skewness of some indices exceeded a value of 0.5 . These indicators were applied method of transformation values by taking the square root. The data obtained were normalized using the "Minimum-maximum" method. This method helps to eliminate the excessive influence of individual indicators on the integral assessment.

Since the study used only indicators-growth stimulants, the normalization formula has the form:

$$
X_{i}=\frac{X-X_{\min }}{X_{\max }-X_{\min }}
$$

where $x_{i}$-normalized value of the indicator;

$x$ - actual value of the indicator under consideration;

$x_{\max }$ - the highest value of the indicator under consideration;

$x_{\min }$ - the lowest value of the indicator under consideration.

TABLE I INDICATORS USED TO ASSESS THE IMPACT OF HUMAN AND INNOVATION POTENTIALS IN THE REGION'S ECONOMIC GROWTH

\begin{tabular}{|c|c|c|}
\hline Variable & Indicator & Justification \\
\hline \multirow[t]{3}{*}{ Human development } & $\begin{array}{l}\text { Government spending on } \\
\text { education }\end{array}$ & $\begin{array}{l}\text { Education is one of the most important factors of economic growth that } \\
\text { contribute to improving the quality of human capital. Human capital development } \\
\text { means the mobilization of public resources. }\end{array}$ \\
\hline & $\begin{array}{l}\text { Percentage of the employed } \\
\text { population with higher } \\
\text { education }\end{array}$ & $\begin{array}{l}\text { The direct link between the quality of human capital and the quality of } \\
\text { education as its main component is scientifically proven. This is especially true } \\
\text { for higher education, as comparative analysis has shown that the level of } \\
\text { employment increases as the level of education increases. }\end{array}$ \\
\hline & $\begin{array}{l}\text { Per capita income of the } \\
\text { population }\end{array}$ & $\begin{array}{l}\text { The income of the population is of key importance for the quality of human capital, } \\
\text { as it affects the level of education and health of the population. }\end{array}$ \\
\hline \multirow[t]{3}{*}{ Innovative potential } & $\begin{array}{l}\text { Costs of technological } \\
\text { innovation }\end{array}$ & $\begin{array}{l}\text { The prospects for economic development of the region directly depend on } \\
\text { the development and implementation of technological innovations. An important } \\
\text { aspect is the financial support of technological innovations, which is current and } \\
\text { capital expenditures performed at both the micro and macro levels. }\end{array}$ \\
\hline & $\begin{array}{l}\text { Innovative activity of the } \\
\text { organization }\end{array}$ & $\begin{array}{l}\text { Studies of economic models in developed countries show that rapid economic } \\
\text { growth correlates with a high level of innovation activity of enterprises in the } \\
\text { region. [21] }\end{array}$ \\
\hline & $\begin{array}{l}\text { Share of the number of } \\
\text { researchers in the total } \\
\text { population }\end{array}$ & $\begin{array}{l}\text { Many government development strategies are based on the assumption that } \\
\text { investment in research contributes to the development of the region and increases } \\
\text { its competitiveness. [16] }\end{array}$ \\
\hline $\begin{array}{l}\text { Economic growth of the } \\
\text { region }\end{array}$ & $\begin{array}{l}\text { Gross regional product per } \\
\text { capita }\end{array}$ & $\begin{array}{l}\text { The gross regional product per capita is a Central indicator that characterizes the } \\
\text { socio-economic development of the region. }\end{array}$ \\
\hline
\end{tabular}

\section{Calculation of integral indicators.}

Calculation of integral indicators by groups and summary integral indicator by averaging the obtained values of indicators using the arithmetic mean simple method.

4. Grouping of the Central Federal district regions by the value of the three designated variables.

Subjects were grouped according to the median value of the integral values of the variables: human potential, investment potential, and gross regional product per capita:

Group 1-subjects where all three indicators exceed the median level;

Group 2-subjects where all three indicators do not exceed the median value;

Group 3 - subjects in which the level of human and investment potential exceeds the median value, and the level of GRP per capita is lower;

Group 4 - subjects where the level of human potential and GRP per capita is higher than the median, and innovation potential is lower;

Group 5 - subjects where the level of innovation potential is higher than the median, and the level of GRP per capita and human potential is lower.
Group 5 - subjects where the level of human potential is higher than the median value, and the level of innovation potential and GRP per capita is lower;

Group 7 - subjects where GRP per capita exceeds the median value, and the other two variables are lower;

Group 8 - subjects where the level of innovation potential and GRP per capita exceeds the median value, but the level of human potential does not exceed.

\section{Analysis of Variance.}

In order to assess the influence of the factors under consideration on the resulting trait, a variance analysis was performed, which also allows us to quantify the proportion of variation. To assess the degree of influence of a grouped attribute on the resulting indicator, an empirical correlation relation was used:

$$
\eta=\sqrt{\frac{\delta^{2}}{\sigma^{2}}}
$$

where $\delta^{2}$ - the between-group variance

$\sigma^{2}$ - total variance 


\section{MAIN PART}

The following data for the Central Federal district were used for the study, table 2 .

In the Central Federal district, the level of GRP per capita exceeds the average value in the Russian Federation by about $29.1 \%$. According to these characteristics of assessing the level of human and innovative potential, we can distinguish such regions as Moscow, Moscow, Yaroslavl, Kaluga, Voronezh, Tver, Lipetsk and Belgorod regions whose indicators exceed the national average or are as close as possible to it. Such regions as Ivanovo, Bryansk, Oryol, Kostroma have low values of human and innovative potential development, as well as low rates of economic growth.
Due to the revealed heterogeneity in the development of the Central Federal district regions, it became necessary to divide these regions into groups in order to form a further regional policy aimed at reducing the level of differentiation. So, as a result of the research conducted using the proposed methodology, we obtained a grouping of regions based on median values in three areas of regional development: economic, innovative and human capital development. 4 groups of regions of the Central Federal district were identified, and the distribution of regions is clearly shown in figure 1 .

TABLE II

INDICATORS FOR ASSESSING INNOVATION AND HUMAN CAPITAL BY THE CENTRAL FEDERAL DISTRICT REGIONS, 2018.

\begin{tabular}{|c|c|c|c|c|c|c|c|}
\hline \multirow[t]{2}{*}{ Region } & \multicolumn{3}{|c|}{ Human development } & \multicolumn{3}{|c|}{ Innovative potential } & \multirow[b]{2}{*}{ 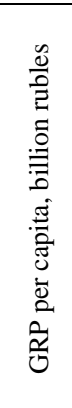 } \\
\hline & 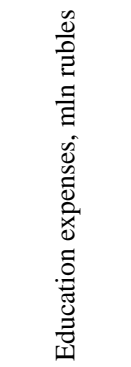 & 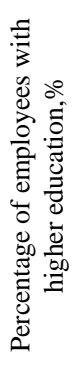 & 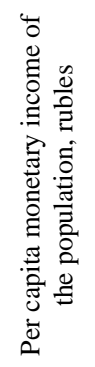 & 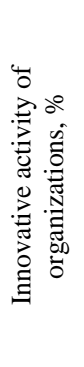 & 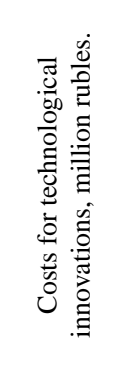 & 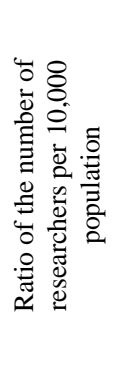 & \\
\hline Russian Federation & 30156000 & 34,2 & 33178 & 12,8 & 1472822,3 & 30 & 578,7 \\
\hline Central federal district & 796109,5 & 39,3 & 43687 & 16,2 & 494893,3 & 36 & 747,5 \\
\hline Belgorod region & 29379,8 & 34,2 & 33178 & 18,2 & 20703,2 & 10 & 559,2 \\
\hline Bryansk region & 17175 & 39,3 & 43687 & 8,2 & 2164,6 & 6 & 272,7 \\
\hline Vladimir region & 22526,2 & 31,7 & 30778 & 13,0 & 7249,8 & 37 & 321,1 \\
\hline Voronezh region & 35442,5 & 30,5 & 26585 & 17,1 & 12725,1 & 47 & 404,8 \\
\hline Ivanovo region & 13155,8 & 27,4 & 23539 & 8,1 & 154,7 & 6 & 196,0 \\
\hline Kaluga region & 17789,9 & 32,9 & 30289 & 16,6 & 10401,3 & 89 & 461,0 \\
\hline Kostroma region & 10734,8 & 29,3 & 24503 & 5,8 & 685,3 & 2 & 281,6 \\
\hline Kursk region & 20185,2 & 31,4 & 29129 & 8,9 & 2928,5 & 23 & 385,6 \\
\hline Lipetsk region & 18163,6 & 26 & 23716 & 23,6 & 10461,5 & 5 & 506,1 \\
\hline Moscow oblast & 189530 & 35,1 & 27275 & 14,1 & 136922,6 & 114 & 556,4 \\
\hline Orel region & 11505,2 & 30,8 & 30010 & 8,6 & 2924,5 & 10 & 310,4 \\
\hline Ryazan region & 18382,3 & 41,4 & 44707 & 16,4 & 3752,4 & 23 & 342,7 \\
\hline Smolensk region & 13115,8 & 36,2 & 24895 & 10,8 & 2984,7 & 9 & 330,8 \\
\hline Tambov region & 14576 & 31 & 25441 & 11,0 & 5797,3 & 10 & 323,6 \\
\hline Tver region & 19012,6 & 31,1 & 25888 & 15,6 & 2023,6 & 29 & 345,9 \\
\hline Tula region & 26198,9 & 28,1 & 26828 & 15,4 & 18717,7 & 28 & 428,3 \\
\hline Yaroslavl region & 24071,2 & 25 & 25125 & 14,2 & 4717,2 & 49 & 444,0 \\
\hline Moscow & 295164,7 & 30,8 & 27208 & 33,8 & 249579,4 & 162 & 1423,6 \\
\hline
\end{tabular}




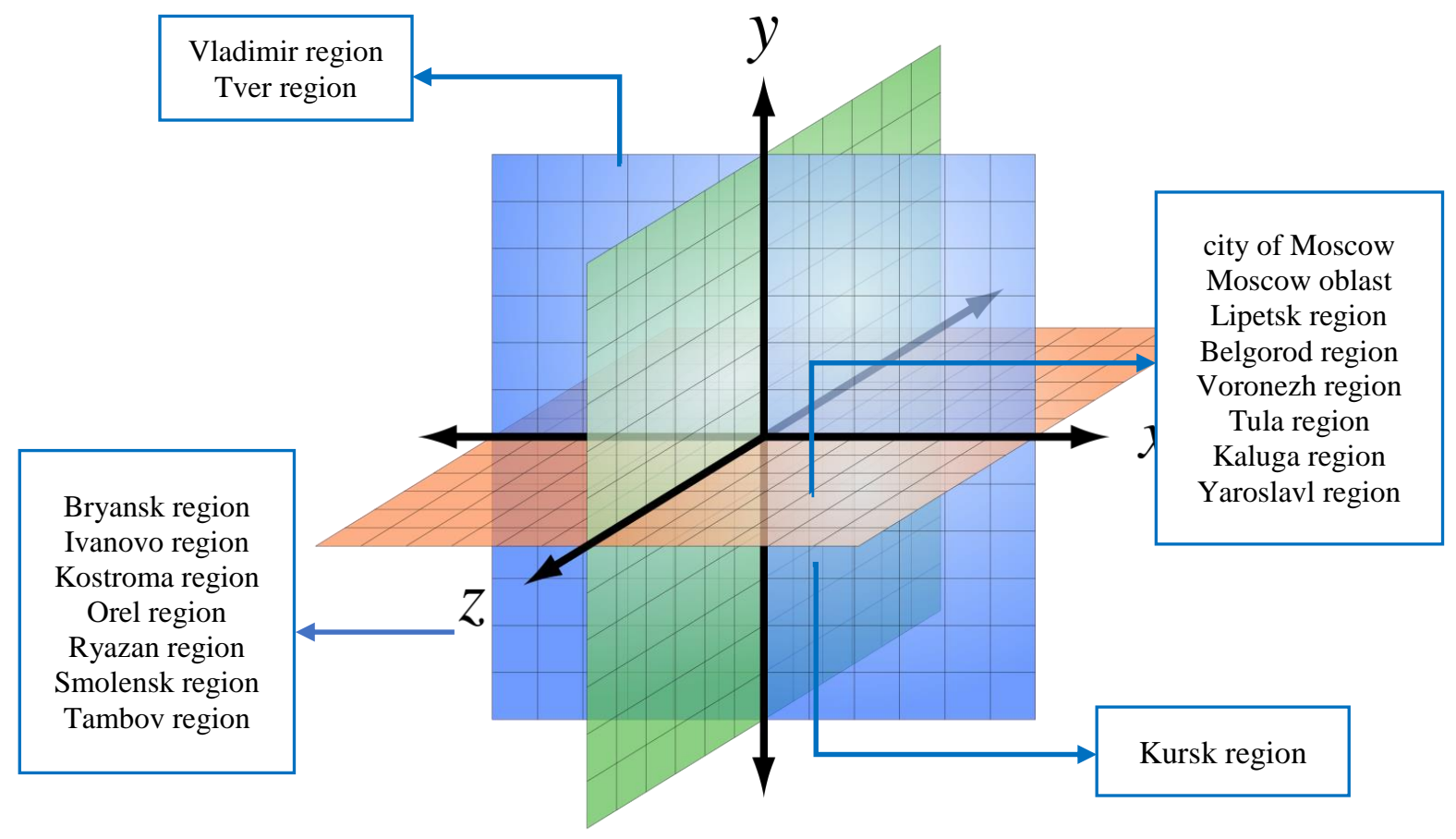

Fig1 .Grouping of Central Federal district regions by GRP level, human capital and investment development ( $\mathrm{y}$ - level of GRP per capita; $\mathrm{x}$ - level of human development; $\mathrm{z}$ - level of innovation potential development)

The figure shows that most of the regions of the Central Federal district: Moscow region, Moscow, Voronezh, Kaluga, Lipetsk, Belgorod, Tula, Yaroslavl are in the first group. This group is characterized by values above the median in all three directions. This means that economic growth in these regions provides high human capital and innovation potential.

The next largest group is group 2-these are the regions where the values are lower than the median in all areas of development: Bryansk, Oryol, Ivanovo, Kostroma, Ryazan, Smolensk and Tambov regions. The low level of human and innovative potential reduces the growth rate of GRP per capita.

Based on the obtained characteristics in the above groups, it can be concluded that the dynamics of human and innovation potential development determines the growth rate of GRP per capita and there is a direct relationship between them.

Group 4 includes only the Kursk region, where the growth of GRP per capita is largely due to the dynamics of human potential. At the same time, innovation processes in this region are poorly developed and there is a need to build up innovation potential. Having high-quality human potential, which in turn acts as the main factor of innovative growth in the region, can provide high rates of economic development to the regions of this group.

Vladimir and Tver regions are included in the fifth group. They have a high innovation potential, but due to the low level of human capital in the regions of this group, the GRP per capita value is lower than the median.

This grouping revealed that human capital and innovation potential are important factors in the economic development of the region. To assess the strength of the influence of the selected factors on the growth of GRP per capita, we conduct a variance analysis and, based on the value of the empirical correlation ratio, show the share of variation in the gross regional product, explaining the variation in human capital and innovation potential.

Let's group the subjects of the Central Federal district by the median value of human capital and the median value of innovation potential. Data for calculating all types of GRP variance per capita are presented in tables 3 and 4 . 


\begin{tabular}{|c|c|c|c|c|}
\hline Groups of regions by level of human potential & Number of areas & $\begin{array}{c}\text { The average level of } \\
\text { GRP per capita }\end{array}$ & $\sigma_{i}^{2}, \%$ \\
\hline 1 & 2 & 3 & 4 & 5 \\
\hline Below the median value & 9 & 340,6 & 3820,6 & 12,4 \\
\hline Above the median value & 7 & 468,2 & 2744,2 & 22,3 \\
\hline Total & 17 & 380,6 & & 13,2 \\
\hline
\end{tabular}

TABLE IV GROUPING OF REGIONS OF THE CENTRAL FEDERAL DISTRICT BY THE LEVEL OF INNOVATION POTENTIAL, 2018

\begin{tabular}{|c|c|c|c|c|}
\hline Groups of regions by level of human potential & Number of areas & $\begin{array}{c}\text { The average level of } \\
\text { GRP per capita }\end{array}$ & $\sigma_{i}^{2}, \%$ \\
\hline 1 & 2 & 3 & 4 & 5 \\
\hline Below the median value & 8 & 305,4 & 2803,5 & 17,3 \\
\hline Above the median value & 9 & 447,4 & 6272,2 & 17,7 \\
\hline Total & 17 & 380,6 & 4639,9 & 25,8 \\
\hline
\end{tabular}

According to the table, you can see that the average of the group variances is 2744.2 . the inter-Group variance is determined based on columns 2 and 3 of table 3 and is 4455.5 . According to the addition rule, we calculate the total variance-7199.8. it is Important to note that in order for the results to be statistically significant, it is necessary that the coefficient of variation does not exceed 33\% for each group and for the whole population. It is for this purpose that the Moscow region was excluded from observation (its inclusion violates the homogeneity of the studied population).

So, based on the obtained variance values, we have:

$$
\begin{gathered}
\eta^{2}=\frac{4455,5}{7199,8}=0,618 \\
\eta=\sqrt{0,618}=0,787
\end{gathered}
$$

The obtained values indicate that the variation in GRP per capita by $61.8 \%$ is explained by the variation in human potential. An empirical correlation ratio of 0.787 indicates that there is a close relationship between the studied features.

The average of the group variances is 4639.9 , the inter group variance is 5023.3 , and the total variance according to the addition rule is 9663.2 .

Based on the variance values, we have:

$$
\begin{gathered}
\eta^{2}=\frac{5023,3}{9663,2}=0,520 \\
\eta=\sqrt{0,520}=0,720
\end{gathered}
$$

The results of calculations show that $52.0 \%$ of the variation in GRP per capita is due to changes in the innovation potential. The value of the empirical correlation ratio $(0.720)$ indicates the presence of a close relationship between the studied features. The results obtained can be considered statistically significant, since the coefficient of variation for the studied data does not exceed $33 \%$.

\section{CONCLUSION}

Based on the analysis, the following conclusions can be formulated
- human and innovative potential are the driving factors of the region's economic development;

- high human potential is the main condition for the development of innovation processes in the region;

- half of the regions of the Central Federal district have low human potential;

- $\quad$ some areas need to activate innovation processes in order to form a positive trend in economic development.

In order to improve the qualitative and quantitative characteristics of human potential, it is necessary to ensure a high standard of living for the population in the region by developing the social sphere. Favorable living conditions in the region will help attract and accumulate human capital, the quality of which will determine the vector of innovative development of the region's economy. Since the development of innovations and activation of high-tech production is impossible without the participation of human resources. Therefore, when developing regional development Strategies, the targets should primarily be the growth of quality of life indicators that would ensure a high level of human potential in the region. This will help to increase the level of innovation activity and the growth of the region's economy.

\section{ACKNOWLEDGMENT}

The research was carried out within the framework of the state assignment of NRU BelSU FZWG-2020-0016 (0624-2020-0016), the topic of the project "Fundamental foundations of global territorial and industry specialization in the context of digitalization and technology convergence".

\section{REFERENCES}

[1] M.M. Abidokov, "The impact of innovative activity on the economic growth of the region", Bulletin of ASU. Economic Series, 4 (230), 2018, pp. 45-51.

[2] A. Alesina, D. Podrik, "Distributional policy and Economic Growth", Quarterly Economic Journal, vol. 109, I. 2,1994, pp. 465-490.

[3] E.M. Akhmedova, "Evaluation of the impact of education on the economic development of the country", International Journal of 
Innovative Technologies in Economics, vol. 3 (23), 2019. Doi: 10.31435/rsglobal_ijite/30042019/6455.

[4] R. J. Barro, H. Sala-I-Martin. Economic growth; TRANS. from English, Moscow, binom. Laboratory of Knowledge, 2010, 824 P.

[5] G. Becker, Human behavior: an economic approach: Selected papers on economic theory, Moscow: Higher school of Economics, 2003, p 582.

[6] A. I. Bogomolov, V. P. Nevezhin, "The impact of education expenditure on economic growth of the Russian Federation" Chronosequence, 1(9), 2018, pp. 17-21.

[7] A.V. Bozhechkova, T. L. Klyachko, A. Yu. Knobel, A. N. Loshenkova, I. L. Lyubimov, S. G. Sinelnikov-Murylev. Education and economic growth, Moscow, 2019, $120 \mathrm{p}$.

[8] Yu. G. Bychenko, A.M. Pichtelev, "Human development in military assessments", Power. 2019, vol. 27, No. 1, pp. 209-216 https://doi.org/10.31171/vlast.v27i1.6254.

[9] O.G. Golichenko, "National innovation systems: from the concept to the methodology of research", Economic issues, 7, 2014. Doi: 10.32609/0042-8736-2014-7-35-50.

[10] G. M. Grossman, E. Helpman. Innovations and growth in the world economy, Cambridge: MIT Press, 1991, 384 p.

[11] A. I., Dobrynin, L. S. Tarasevich, Economic theory: textbook, St. Petersburg, 2004, $544 \mathrm{p}$.

[12] S. A. Dyatlov, Fundamentals of the theory of human capital, St. Petersburg, 1994, $160 \mathrm{p}$.

[13] T.V. Yermoshina, "Spending on technological innovations as a priority factor in the development of the national innovation system", Bulletin of Eurasian Science, vol. 11 (3), 2019, P. 13.

[14] D.V. Zinkov, N.A. Sushkova, "The importance of the quality of human capital in the modernization of the country's economy", Audit and financial analysis, No. 4, 2012, pp. 346-349.

[15] V.A. Ilyin, A.A. Shabunova, "On some trends in the economic development of Russia and the region", Sociological Studies, 2015 , No. 8, pp. 34-41.

[16] M.A. Kamenskikh, "Research of the influence of universities on regional economic development", Regional Economy: Theory and Practice, No. 42, 2014, pp. 12-20.

[17] R.I. Kapelyushnikov, Transformation of human capital in the Russian society (based on the materials of the "Russian monitoring of the economic situation and health of the population"), Moscow, Foundation "Liberal Mission", 2010, 196 p.

[18] M. M. Kritan, The theory of human capital as a primary factor of economic reform: Economic theory. and economic reform, St. Petersburg, 1995, pp. 5-28.

[19] R. Lucas, "On the mechanics of economic development", Journal of Monetary Economics, 1988, vol. 22, pp. 3-42.

[20] J. Mincer, The production of human capital and the lifccycle of earnings: Variations on a Theme, Working Paper of the NBER, No 4838, 1994

[21] O. S. Mariev, K. M. Nagieva, V. L. Simonova, "Management of factors of innovative activity of Russian regions on the basis of econometric modeling": Manager, vol. 11, no. 1, 2020, pp. 57-69. Doi: 10.29141/2218-5003-2020-11-1-6.

[22] E.V. Popov, M.V. Vlasov, D.M. Kochetkov "Influence of the knowledge economy on the economic development of Russian regions: measurement and main points for practice", Bulletin of the Perm University. Economics series, Bulletin of the Perm University. Economics, 2016, no. 4 (31), pp. 106-116. doi: 10.17072/1994-99602016-4-106-116.
[23] N. M. Rimashevskaya, V. K. Bochkareva, L. A. Mironova, E. V. Mochalova, M. S. Toksanbayeva, "Human potential of Russian regions", Population, 2014, No. 1, pp. 84-141.

[24] N. M. Rimashevskaya, V. G. Dobrokhleb, "Efficiency of human potential in the " New " economy", Population, No. 2, Moscow, 2010, pp. 10-17.

[25] P. M. Romer, "Increasing returns and long-term economic growth", Journal of Political Economy, 1986, no. 94 (5). pp. 1002-1037.

[26] A. Smith, A study on the nature and causes of the wealth of nations: ed. Abalkin L. I., Moscow, 1980.

[27] E.A. Stryabkova, A. S. Glotova, I. N. Titova, Yu. V. Lyshchikova, I. V. Chistnikova, "Modeling and forecasting of socio-economic development of the region", Journal of Sociological Research, 2018, pp. 404-410.

[28] World Bank,. The possibility of re-mapping : the most effective use of the economic potential of the Russian regions. World Bank, Washington, 2018, https://openknowledge.worldbank.org/handle/ 10986/29732 (accessed 25.10.2020) 